ORIGINAL RESEARCH PAPER

\title{
RP-HPLC-PDA-ESI-MS/MS SCREENING OF BIOACTIVE COMPOUNDS FROM DEGLA-BEIDA DATES: CONVENTIONAL AND GREEN EXTRACTION TECHNOLOGIES
}

\author{
KAHINA DJAOUD ${ }^{1 *}$, MARIA DAGLIA ${ }^{2}$, AROLD J. T. SOKENG ${ }^{2}$, FERRIEL KERMICHE ${ }^{1}$, \\ LYNDA ARKOUB $^{1,3}$, KHODIR MADANI $^{1,4}$, LILA BOULEKBACHE MAKHLOUF ${ }^{1}$ \\ ${ }^{1}$ Laboratoire de Biomathématiques, Biophysique, Biochimie, et Scientométrie, Faculté des Sciences de la Nature \\ et de la Vie, Université de Bejaia, 06000 Bejaia, Algérie \\ ${ }^{2}$ Department of Drug Sciences, Medicinal Chemistry and Pharmaceutical Technology Section, University of \\ Pavia, Pavia, Italy \\ ${ }^{3}$ Laboratoire de Biomathématique, Biophysique, Biochimie, et Scientométrie, Faculté des Sciences Biologiques et \\ des Sciences Agronomiques, Université de Tizi Ouzou, 15000, Algérie. \\ ${ }^{4}$ Centre de recherche en technologie agro-alimentaire, Route de Targa-Ouzemour, 06000, Bejaia, Algérie. \\ *Corresponding author:kahinadjaoud10@gmail.com
}

Received on 17 January 2020

Revised on 23 April 2020

\begin{abstract}
Date fruits have vital therapeutic properties, in the way that they represent an inexhaustible source of bioactive compounds such as polyphenols. Therefore, the objective of this work was to evaluate the phytocomposition by High Performance Liquid Chromatography (RP-HPLC-PAD-ESI-MS/MS) of the optimized microwaveassisted extraction (MAE) phenolic extract by using the response surface methodology (RSM) compared to the ultrasound-assisted and conventional extractions (UAE and $\mathrm{CE}$ ), and to test its antioxidant activity in vitro. The resulting regression model indicated that a quadratic polynomial model was best suited for the spectrophotometrically determined total phenolics. The maximum total phenolic content, TPC, $(4.27 \pm 0.09 \mathrm{mg} \mathrm{GAE} / \mathrm{g} \mathrm{DW})$ was obtained with a $50 \%(\mathrm{v} / \mathrm{v})$ ethanol's concentration, a $700 \mathrm{~W}$ microwave power and an extraction time of 2.42 minutes. HPLC analysis revealed the presence of organic sugars and acids, nucleoside, carotenoids, proanthocyanidins, lignans, flavonols, flavones, saponin and sterol glucosides. The MAE phenolic extract showed $58.72 \pm 0.29 \%$ DPPH radical scavenging activity and a $1.88 \pm 0.09 \mathrm{mg}$ Asc AE $/ \mathrm{mL}$ reducing power.
\end{abstract}

Keywords: Dates, microwave-assisted extraction (MAE), phenolic compounds, optimization, antioxidant activity, HPLC-PAD-ESI-MS/MS analysis

https://doi.org/10.35219/foodtechnology.2020.1.04 


\section{Introduction}

Date palm is a fundamental species of the oasis ecosystem, its fruit (Phoenix dactylifera L.) being an important crop in the arid and semiarid regions of the world and is marketed globally as a high-value fruit (Abbès et al., 2013, Besbes et al., 2009, Chandrasekaran and Bahkali, 2013). The cultivars characterized by a low commercial quality known as common cultivars are less appreciated and account for approximately $30 \%$ of the Algerian dates production (Chibane et al., 2007). It was reported that second-grade dates (with a hard texture) from three potential Tunisian cultivars (Deglet Nour, Allig and Kentichi) contain the same levels of sugar, fiber and phenolics (Besbes et al., 2009).

There are thousands of naturally occurring antioxidants that belong to several different classes of compounds (e.g. carotenoids, polyphenols, polyamines, tannins and catechins). Polyphenols are the most abundant natural antioxidants present in plants and plant by-products. Fresh fruits and vegetables are the greatest sources of natural antioxidants and their consumption has been positively related to a decrease of the risk of chronic conditions such as cancer, atherosclerotic heart disease, neurological disorders, including Alzheimer's and Parkinson's diseases (Chu et al., 2002). The phenolics with a high antioxidant activity have been identified in several agro-industrial by-products.

Microwave assisted-extraction is a recently developed technique which has been widely applied for the extraction of organic compounds from environmental samples (Camel, 2000). In the last two decades, new investigations have been prompted by an increasing demand of more efficient extraction techniques, amenable to automation. Shorter extraction times, reduced organic solvent consumption, energy and costs saved were the main tasks pursued. This technique's inherent advantages compared to the traditional conventional solidliquid extraction techniques have drawn interest (Ballard et al., 2010; Dai et al., 1999; Venkatesh and Raghavan, 2004). Driven by these goals, the advances in the microwave extraction have resulted in a number of innovative techniques such as microwave-assisted solvent extraction, vacuum microwave air microwave distillation, microwave-headspace extraction, microwave hydro-diffusion and gravity, and solvent-free microwave extraction. One of the most successful stories of the twenty-first Century has been the partial replacement of conventional extraction processes with "green" procedures (reducing energy, time, solvent, and waste) based on microwave irradiation (Chemat et al., 2012).

The overall objective of this research was to optimize the extraction of bioactive compounds from Phoenix dactylifera L. by determining the optimal conditions required for the microwave-assisted extraction of total phenolic compounds (TPC) from common dates, and the comparison of the obtained results to those of the ultrasound-assisted and conventional methods, using the response surface methodology through Box-Behnken design (BBD) with a quadratic regression model. Then, the evaluation of the phytochemical and antioxidant activity of the best extracts in terms of the TPC yield of the dates' extract was also assessed through a RP-HPLC-PAD-ESI-MS/MS analysis. 


\section{Materials and methods}

\section{Chemicals and plant material}

The HPLC-grade water was obtained from a LC-Pak ${ }^{\mathrm{TM}}$ Millex system (Millipore Corporation, Billerica, MA, USA). Formic acid, MS grade methanol, citric acid, galacturonic acid, malic acid, glucose, sucrose, gallic acid, and caffeine were obtained from Sigma-Aldrich, St. Louis, MO, USA. Quinic acid, catechin, procyanidin $\mathrm{B}_{1}$, procyanidin $\mathrm{C}_{1}$, kaempferol glucoside, kaempferol, rutin, and quercetin rhamnoside were obtained from PhytoLab, Vestenbergsgreuth, Germany.

The "Degla-Beida" dates used in this study present a dry nature and a hard texture, that are found in the palm groves of South-East Algeria. The choice of this variety is justified by its relative abundance on the national territory, its low market value, its long shelf life due to its dry nature, its taste and nutritional quality (energy source represented by its high sugar content) (Djaoud et al., 2020). The dates were washed with tap water followed by distillated water, pitted and deposited in a drying oven at $40^{\circ} \mathrm{C}$ until up to a constant weight. Then, the dried samples were ground into a fine powder, which was passed through a standard sieve ( $125 \mu \mathrm{m}$ diameter) and only the fraction with the particle size $\leq 125 \mu \mathrm{m}$ was used. Finally, the powder was stored in the darkness (Djaoud et al., 2019).

\section{Phytochemical analysis}

\section{Extraction of date polyphenols}

Three extraction methods were used for the extraction of the dates' polyphenols: microwave-assisted extraction (MAE), ultrasound-assisted extraction (UAE) and conventional extraction (CE).

\section{Microwave-assisted extraction (MAE)}

The MAE experiments for the extraction of polyphenols from Phoenix dactylifera L. were executed using a laboratory microwave system (MAXMOS23S, Maxipower, China). This apparatus operates at $2450 \mathrm{MHz}$ with a maximum delivered power of $900 \mathrm{~W}$. These experiments were conducted with date powder (1g) and solvent added (water, ethanol, methanol and acetone) at different concentrations $(20,40,60,80$ and $100 \% \mathrm{v} / \mathrm{v})$, at room temperature. The samples were treated under different selected conditions $(100,300,500,700$ and $900 \mathrm{~W}$ of microwave power, and 1:20, 1:40, 1:60, 1:80 and 1:100 g/mL solvent-to-solid ratios). Indeed, the effect of the type of solvent, the ethanol/water mixture (\%), the microwave power $(\mathrm{W})$, the microwave irradiation time $(\mathrm{min})$ and the solvent-tosolid ratio on the extraction yield of TPC were studied. After each experiment, the extract was filtered through filter paper. The parameters that had the greatest influence on the extraction of polyphenols using MAE were selected for the response surface methodology study.

\section{Ultrasound-assisted extraction (UAE)}

The ultrasound-assisted extraction of dates' polyphenols was performed in an ultrasonic bath (mod.2510E-DTH, Mexico, USA), with the working frequency 
fixed at $42 \mathrm{kHz}$, as described by Abu-Reidah et al. (2017) with slight modifications. $1 \mathrm{~g}$ of date powder was extracted with $20 \mathrm{~mL}$ of ethanol $50 \%(\mathrm{v} / \mathrm{v})$, for $60 \mathrm{~min}$ at room temperature. Afterwards, the extract was paper filtered, and the volume of the solution was adjusted with ethanol and stored at $4{ }^{\circ} \mathrm{C}$.

\section{Conventional extraction (CE)}

The dates' phenolic compounds were extracted according to the method of AlTurki et al. (2010), with slight modifications. One gram of date powder was extracted with $20 \mathrm{~mL}$ of ethanol $50 \%(\mathrm{v} / \mathrm{v})$ to minimize the solubility of sugars. The mixed ethanol-sample material system was kept under magnetic stirring on a shaker for $60 \mathrm{~min}$ at room temperature. The extracts were then paper filtered. The final volume of the solution was adjusted with the ethanol $50 \%$ and stored at $4{ }^{\circ} \mathrm{C}$.

\section{Total phenolic content (TPC)}

The amount of total phenolics was determined using the Folin-Ciocalteu reagent and gallic acid as a standard as described by Georgé et al. (2005). The results were expressed as mg gallic acid Equivalent per gram dry weight (mg GAE/g DW).

\section{Evaluation of the antioxidant activity}

Two different methods were tested: the scavenging of the DPPH radical and the reducing power. The ability of the extract to scavenge the DPPH free radical was determined by the method of Milardović et al. (2006), and the reducing power was assessed according to the method of Oyaizu (1986).

\section{RP-HPLC-PAD-ESI-MS/MS analysis}

The chromatographic analysis of the optimized phenolic extract, obtained by microwave-assisted extraction under the optimal conditions $\left(\mathrm{X}_{1}\right.$-Ethanol concentration, $\mathrm{X}_{2}$-microwave power and $\mathrm{X}_{3}$-irradiation time) suggested by the Design-Expert ${ }^{\circledR}$ software, were performed using a Thermo Finnigan Surveyor Plus HPLC apparatus equipped with a quaternary pump, a Surveyor UV-Vis PDA detector, and a LCQ Advantage max ion trap mass spectrometer (all from Thermo Fisher Scientific, Waltham, MA), coupled through an ESI source. The RP-HPLCPAD-ESI-MS/MS data were acquired under positive and negative ionization modes, using the Xcalibur software. With this aim, the ion trap operated in full scan (100-2000 m/z), data dependent scan and $\mathrm{MS}^{\mathrm{n}}$ modes; in fact, when greater discrimination was required, additional targeted $\mathrm{MS}^{2}$ and $\mathrm{MS}^{\mathrm{n}}$ experiments were performed on the selected pseudomolecular ions.

To optimize the MS operating conditions a preliminary experiment was performed: $10 \mu \mathrm{g} / \mathrm{mL}$ caffeine $\left(\mathrm{H}_{2} \mathrm{O} / \mathrm{MeOH}: 50 / 50\right.$ with $0.1 \%$ formic acid) and $10 \mu \mathrm{g} / \mathrm{mL}$ gallic acid $\left(\mathrm{H}_{2} \mathrm{O} / \mathrm{MeOH}: 50 / 50\right.$ with $0.1 \%$ formic acid) solutions were directly infused in the ESI interface at a flow rate of 25 $\mu \mathrm{L} / \mathrm{min}$ into the mass spectrometer. The optimized conditions were as follows: 60 arbitrary units of sheat gas, a capillary temperature of $220{ }^{\circ} \mathrm{C}$, auxiliary gas 20 and 25 spray voltage 4.5 and $5 \mathrm{kV}$, capillary voltage -26.13 $\mathrm{V}$ and $35 \mathrm{~V}$, respectively for negative and positive ionization mode. The separation was achieved on a Kinetex XB RP18 80A (150 x $4.6 \mathrm{~mm} ; 5 \mu \mathrm{m})$ column, protected by the corresponding guard column, both from Phenomenex, 
California, USA, operating at $25{ }^{\circ} \mathrm{C}$. A gradient elution was executed with acidified water $(0.1 \%$ formic acid) as the A mobile phase and methanol as the $\mathrm{B}$ mobile phase, at a flow rate of $0.3 \mathrm{~mL} / \mathrm{min}$. The elution gradient for the separation of the dates extract polyphenols consisted of moving from: 10 to $70 \% \mathrm{~B}$ in $104 \mathrm{~min}, 70$ to $80 \% \mathrm{~B}$ in $5 \mathrm{~min}, 80$ to $100 \% \mathrm{~B}$ in $5 \mathrm{~min}$, a $5 \mathrm{~min}$ isocratic of $100 \% \mathrm{~B}, 100$ to $10 \% \mathrm{~B}$ in $5 \mathrm{~min}$ and finally an isocratic of $10 \%$ $\mathrm{B}$ for $6 \mathrm{~min}$. The sample tray temperature was set at $4^{\circ} \mathrm{C}$ and the injection volume was $5 \mu \mathrm{L}$. The chromatograms were recorded at $\lambda 254,280,330 \mathrm{~nm}$ and the spectral data were collected in the range of $200-800 \mathrm{~nm}$ for all the peaks. The compounds were characterized on the basis of their UV-Vis and mass spectra, checking the molecular ion and the fragment ions against the fragmentation patterns of the standard molecules where possible and the molecules described in the literature.

\section{Experimental design}

The response surface methodology was employed to explore the variables that affect the microwave extraction and this approach enables the overall number of experiments and possible interactions between the variables to be considered.

A Box-Behnken design was developed and a fractional three-level/three-factor experimental design with three replicates at the center point was used to investigate the effects of three independent variables $\left(\mathrm{X}_{1}\right.$-Ethanol's concentration, $\mathrm{X}_{2^{-}}$ Microwave power and $\mathrm{X}_{3}$-Iradiation time) on the extraction yield of the phenolic compounds from the dates' sample.

The independent variables were coded at three levels (-1, 0 and 1$)$ and each level was selected based on the stability of the TPC under the MAE conditions. The complete experimental design consisted of 15 experimental points. The technique described above was used to obtain the surface response by fitting the data to a polynomial model and the effects of each factor while the interactions between the studied factors being also evaluated.

\section{Validation of the optimized solution and predicted model}

To verify the suitability of the quadratic equations in predicting the optimal response values, the verification experiments were carried out under optimal conditions and compared to the predicted values. The extractions under the optimal values were made in triplicate.

\section{Statistical analysis}

All data were presented as mean standard deviations $( \pm$ SD) of three repeated experiments. The influence of each factor on the TPC yield in the single factor experiment for the MAE was statistically assessed by the analysis of variance (ANOVA) and the Tukey's post hoc test with a 95\% confidence level using the XLSTAT Release 10 (Addinsoft, Paris, France). 
Results and discussion

\section{Phytochemical analysis}

Total phenolic compounds (TPC)

Effects of extraction variables

The MAE was strongly affected by several parameters, such as the composition and the volume of the extractant, the microwave power and the extraction time.

Effect of extraction solvent

Ethanol and water are the most appropriate solvents used in the food and nutraceutical industry, because they are easily removed from the final product and they increase the efficiency of the phenolic acids and flavonoids' extraction of (Moraes et al., 2013). Ethanol, methanol, acetone (at 60\% v/v) and distillated water were used to investigate the effect of the extraction solvent on the TPC yield as shown in Table 1. The highest TPC content was detected in the ethanol extract $(2.75 \pm 0.04 \mathrm{mg} \mathrm{GAE} / \mathrm{g})$ followed by methanol and acetone extracts then by the distillated water extract. The obtained results led us to conclude that ethanol was significantly $(p<0.05)$ the best extraction solvent in term of the TPC yield, so that consequently it was selected for the following experiments and for the RSM trial.

\section{Effect of ethanol's concentration}

The different aqueous EtOH mixtures have different dielectric properties in the MAE, and this has a profound effect on the extraction of phenolic compounds (Setyaningsih et al., 2015). The effect of the ethanol's concentration on the extraction efficiency was determined and the extract yields were compared (Table 1). The highest extraction yield was obtained by using $60 \%$ ethanol, this concentration was selected for the following experiments and the $40-80 \%$ range was selected for the RSM study.

\section{Effect of microwave power}

The results indicated a linear rise of the TPC yield from 100 to $700 \mathrm{~W}$. This increase is because of a microwave power increase in that will improve the solubility of the sample for a better extraction efficiency. The microwave power's increment increased the dipole reactions which caused the heat generation in the mixture as a result of the power degeneration. After 700 watts, there was no increase in the yield of TPC. Consequently, $700 \mathrm{~W}$ was selected for the following experiments and the range 500-900 $\mathrm{W}$ was selected for the RSM trial. 


\section{Effect of irradiation time}

The irradiation time is one of the key parameters which influenced the yield of TPC significantly. To study its effect, the experiments were performed for different irradiation times $(1 / 2-5$ min). The results revealed that the TPC yield increased with the irradiation time increment up to 2 minutes. Beyond 2 minutes, a decrease in the yield of TPC from Phoenix dactylifera L. fruit was observed. The changes may be due to the spilling of the material during the pumping associated with the longer irradiation time and the possibility of polyphenol's denaturation. The time of two minutes was selected for the following experiments and the 1-3 min range was selected for the RSM study.

\section{Effect of solvent-to-solid ratio}

The solvent to sample ratio is another important parameter which when applied correctly could decrease the mass transfer barrier and subsequently enhance the extraction yield. It can be optimized using the single factor experiment. This is because the change in the solvent's volume due to different ratio would affect the absorption of the microwave energy in MAE, making the basis of comparison inaccurate (Chan et al., 2014). The increase of the solvent to sample ratio at constant solvent concentration from 20 to $100 \mathrm{~mL} / \mathrm{g}$ decreased the extraction yield of TPC. To avoid the solvent's wastage, the optimum solvent-to-sample ratio at a constant volume for MAE were selected and set to be $20 \mathrm{~mL} / \mathrm{g}$. 


\section{Optimization by RSM}

To study the optimal conditions, an experimental design was developed for most of the dependent variables, which were the concentration of ethanol used as the extract, the microwave power and irradiation time used to develop the extraction. A 15 factorial experimental design was used to study the significance of each variable and the correlation/interaction between them (Table 2).

The combined effect of ethanol's concentration and microwave power on the TPC extraction from date fruit was shown in the surface plot in Figure 1a. The TPC extraction rate proved to be very sensitive in regards to the solvent's concentration modification. It was observed that the extraction of the TPC increased by increasing the ethanol's concentration from 40 to $60 \%$ as well as by increasing the microwave power from 300 to $700 \mathrm{~W}$.

Table 2. Box-Behnken design with the observed responses of the total phenolic content (TPC) yield using the microwave-assisted extraction.

\begin{tabular}{|c|c|c|c|c|c|}
\hline \multirow[t]{2}{*}{ Run } & \multirow[t]{2}{*}{$\mathbf{X}_{1}$} & \multirow[t]{2}{*}{$X_{2}$} & \multirow[t]{2}{*}{$\mathbf{X}_{3}$} & \multicolumn{2}{|c|}{ Recovery of TPC (mg GAE/g) } \\
\hline & & & & Experimental & Predicted \\
\hline 1 & 60 & 500 & 120 & $3.69 \pm 0.01$ & 3.62 \\
\hline 2 & 60 & 500 & 120 & $3.56 \pm 0.03$ & 3.62 \\
\hline 3 & 60 & 700 & 180 & $4.00 \pm 0.06$ & 3.98 \\
\hline 4 & 80 & 300 & 120 & $2.75 \pm 0.03$ & 2.73 \\
\hline 5 & 80 & 500 & 180 & $3.12 \pm 0.02$ & 3.19 \\
\hline 6 & 80 & 700 & 120 & $3.24 \pm 0.04$ & 3.20 \\
\hline 7 & 40 & 700 & 120 & $3.93 \pm 0.08$ & 3.95 \\
\hline 8 & 40 & 300 & 120 & $3.40 \pm 0.03$ & 3.44 \\
\hline 9 & 40 & 500 & 60 & $3.45 \pm 0.05$ & 3.39 \\
\hline 10 & 60 & 300 & 60 & $2.93 \pm 0.05$ & 2.96 \\
\hline 11 & 60 & 500 & 120 & $3.61 \pm 0.02$ & 3.63 \\
\hline 12 & 40 & 500 & 180 & $3.77 \pm 0.08$ & 3.78 \\
\hline 13 & 60 & 300 & 180 & $3.73 \pm 0.06$ & 3.68 \\
\hline 14 & 60 & 700 & 60 & $3.59 \pm 0.01$ & 3.64 \\
\hline 15 & 80 & 500 & 60 & $2.51 \pm 0.05$ & 2.51 \\
\hline
\end{tabular}

Values are mean $\pm 95 \%$ confidence interval.

Nonetheless, a decreasing tendency was observed by further increasing the ethanol's concentration from 60 to $80 \%$. From the contour plot the maximal TPC yield was predicted at the ethanol's concentration of $60 \%$ and microwave power of $700 \mathrm{~W}$.

Figure $1 \mathrm{~b}$ depict the surface plot of the effects of two variables, namely ethanol's concentration and irradiation time on the TPC yield. The ethanol's concentration demonstrated a parabolic extraction on the response which increased from 40 to 60 $\%$ and decreased from 60 to $80 \%$. It was observed also that the extraction of TPC increased with the increase of the irradiation time as well as the ethanol's 
concentration. From this contour plot, the highest values of the TPC extraction can be obtained at an ethanol's concentration of $60 \%$ and an irradiation time of $2 \mathrm{~min}$.

(A)

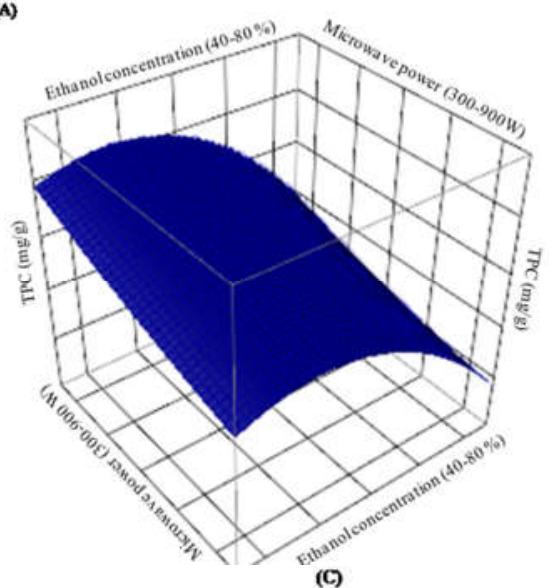

(B)

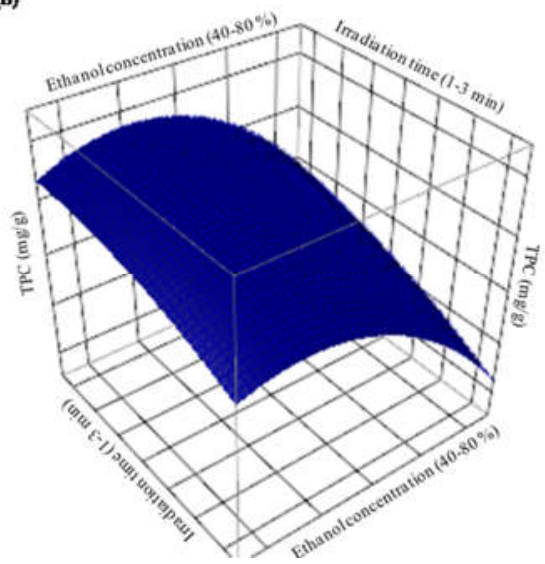

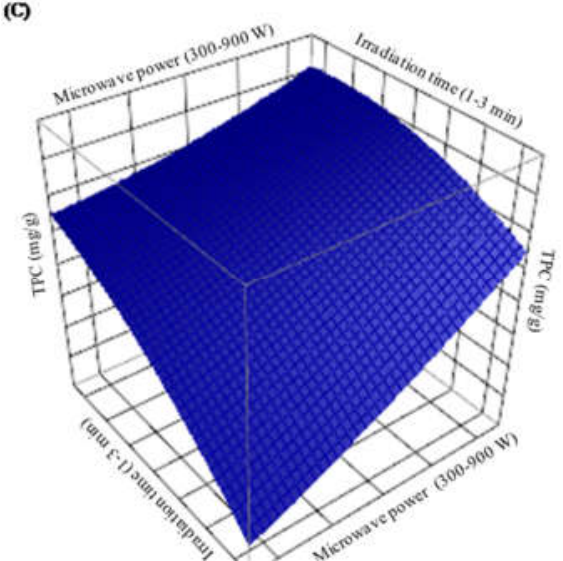

Figure 1. Response surface analysis for the total phenolic yield from Phoenix dactylifera L. by the microwave-assisted extraction with respect to ethanol's concentration and microwave power (a); ethanol's concentration and irradiation time (b) microwave power and irradiation time (c).

The effect of the microwave power and different levels of irradiation time on the extraction of TPC can be predicted from the surface plot as it is shown in Fig. 1c. It was confirmed from Fig. 1c that both of the independent variables had a strong effect on the extraction. The contour plot showed that the maximum extraction efficiency $(4.00 \pm 0.06 \mathrm{mg} \mathrm{GAE} / \mathrm{g} \mathrm{DW})$ was achieved under a $700 \mathrm{~W}$ microwave power and $2 \mathrm{~min}$ irradiation time. Increasing the microwave power from 300 to 700 $\mathrm{W}$ and the irradiation time from 1 to 2 min significantly increased the extraction rate of TPC from Phoenix dactylifera L. fruit. However, the further increase of the irradiation time from 2 to 3 min caused a decrease of the extraction yield. 


\section{Model fitting and statistical analysis}

The response surface methodology (RSM) is an empirical modeling technique. It calculates the correlation between the actual and the forecast outcomes. To attain a suitable model so as to optimize the MAE (Ethanol's concentration, microwave power and irradiation time), the Box-Behnken design (BBD) was used (Table 2).

To understand the effect of the independent factors on the Phoenix dactylifera $\mathrm{L}$. fruit's TPC yield and to determine the optimum solutions, the experimental design was followed. Table 2 presents the experimental data and the anticipated values. The yield of TPC ranged from $2.51 \pm 0.05$ to $4.00 \pm 0.06 \mathrm{mg} \mathrm{GAE} / \mathrm{g} \mathrm{DW}$.

The multiple regression analysis was applied to the experimental data, the response variable and the test variables were related to the following second-order polynomial equation according to the coded values:

$$
\begin{aligned}
Y(T P C) & =3.62-0.37 X_{1}+0.24 X_{2}+0.27 X_{3}-0.01 X_{1} X_{2}+0.07 X_{1} X_{3}-0.10 X_{2} X_{3}-0.32 X_{1}^{2} \\
& +0.03 X_{2}^{2}-0.09 X_{3}^{2}
\end{aligned}
$$

Where $\mathrm{Y}$ is the yield of TPC calculated by the regression model and $\mathrm{X}_{1}, \mathrm{X}_{2}$ and $\mathrm{X}_{3}$ are the coded variables.

To avoid poor or disingenuous response surface results, the adequacy and fitness of the model were checked using the regression analysis and ANOVA (Sangamithra et al., 2015). ANOVA subdivides the total variation of the results into smaller parts coupled with the sources of variation to test the hypotheses about the independent factors (Swamy et al., 2014). Further, the Fisher's statistical test ( $F$-test) analyzed the significance of each individual independent factor.

The ANOVA's results (Table 3) for the quadratic model showed that the polynomial model was statistically significant, as suggested by the high $F$-value $(F=50.80)$ and the low $p$-value $(p<0.0001)$. The $p$ and $F$ values are used to check the significance of each coefficient, while they also indicate the interaction strength between independent variables. The higher the $F$-value and the lower the $p$-value indicate the high significance of the corresponding coefficient.

The $\mathrm{R}^{2}$ and the adjusted $\mathrm{R}^{2}$ confirm the adequacy and suitability of the model. The high values of the determination coefficient $\left(\mathrm{R}^{2}=0.99\right)$ and the adjusted determination coefficient $\left(\mathrm{R}_{\text {adj }}^{2}=0.97\right)$ showed a high degree of correlation between the experimental and the predicted values of the TPC yield. The pure error was very low, indicating the good reproducibility of the obtained data. The model also showed that the lack of fit was statistically insignificant $(p>0.05)$, which further confirmed the validity of the model.

At the same time, our results also demonstrated that the linear coefficients $\left(\mathrm{X}_{1}, \mathrm{X}_{2}\right.$ and $\left.\mathrm{X}_{3}\right)$, the quadratic coefficients $\left(\mathrm{X}_{1}{ }^{2}\right.$ and $\left.\mathrm{X}_{2}{ }^{2}\right)$ and the interaction coefficients $\left(\mathrm{X}_{1} \times \mathrm{X}_{3}\right)$ have significant effects, with low $p$-values $(p<0.05)$. The other coefficients $\left(\mathrm{X}_{3}^{2}, \mathrm{X}_{1} \times \mathrm{X}_{2}\right.$ and $\left.\mathrm{X}_{2} \times \mathrm{X}_{3}\right)$ were found to be insignificant $(p>0.05)$. Moreover, the ethanol's concentration $\left(\mathrm{X}_{1}\right)$ was the most significant parameter that influenced the yield of TPC, followed by microwave power $\left(\mathrm{X}_{2}\right)$ and extraction time $\left(\mathrm{X}_{3}\right)$. 
Table 3. Analysis of variance (ANOVA) for the experimental results obtained by using the microwave-assisted extraction.

\begin{tabular}{|c|c|c|c|}
\hline & Sum of squares & $F$-value & $p$-value \\
\hline Model & 3.62 & 50.80 & $<0.0001$ \\
\hline $\begin{array}{l}\mathrm{X}_{1}-\text { Ethanol } \\
\text { concentration }\end{array}$ & -0.37 & -13.79 & $<0.0001$ \\
\hline $\mathrm{X}_{2}-$ Microwave power & 0.24 & 9.17 & 0.0003 \\
\hline $\mathrm{X}_{3}$-Irradiation time & 0.27 & 10.00 & 0.0002 \\
\hline $\mathrm{X}_{1} \mathrm{X}_{2}$ & -0.01 & -0.26 & 0.8062 \\
\hline $\mathrm{X}_{1} \mathrm{X}_{3}$ & 0.07 & 1.92 & 0.1134 \\
\hline $\mathrm{X}_{2} \mathrm{X}_{3}$ & -0.10 & -2.56 & 0.0506 \\
\hline $\mathrm{X}_{1}^{2}$ & -0.32 & -8.23 & 0.0004 \\
\hline $\mathrm{X}_{2}{ }^{2}$ & 0.03 & 0.74 & 0.4918 \\
\hline $\mathrm{X}_{3}^{2}$ & -0.09 & -2.23 & 0.0763 \\
\hline Residual & 0.03 & & \\
\hline Lack of Fit & 0.02 & 1,50 & 0.42 \\
\hline Pure Error & 0.00 & & \\
\hline $\mathrm{R}^{2}$ & 0.99 & & \\
\hline $\mathrm{R}_{\text {adj }}^{2}$ & 0.97 & & \\
\hline RMSE & 0.07 & & \\
\hline
\end{tabular}

\section{Investigating the model adequacy}

Diagnostic plots ensure the model's adequacy and exhibit the correlation between the actual and the predicted results. The data points were close to the straight line, signifying a close agreement between the two data. It also suggests that the model is capable to select suitable operating conditions to extract the TPC from dates. Further, the normality assumption was verified by plotting a normal probability plot of the residuals. The data was found to lie near the straight line, so that it was concluded that the data was normally distributed.

\section{Comparison between the extraction techniques}

MAE is an innovative technique that has been presenting a special interest. Microwaves consist of a non-ionizing electromagnetic energy that is applied directly to the raw material. They transmit energy which penetrates into the biologic matrix and interacts with the polar molecules, mostly water, generating heat; the heat expands and disrupts the vegetal cell, favoring the extraction of intracellular phytochemical compounds. MAE is a technique frequently used to extract thermolabile compounds (Takeuchi et al., 2008). The UAE technique consists in using mechanic vibrations caused by sound waves with frequencies higher than $20 \mathrm{kHz}$. Sound waves are intrinsically different from electromagnetic waves, because the latter can propagate through the vacuum, while sound waves need a physical medium to propagate.

The mechanic vibrations cause expansion and compression cycles in the medium, creating bubbles which collapse and cause cavitation, instantly creating a high local pressure and intense local heating. These fast changes induce the disruption and thinning of the cell membranes, consequently increasing the mass transfer rate of 
organic substances from the solid matrix to the solvent (Esclapez et al., 2011; Takeuchi et al., 2008). The conventional solid-liquid extraction can generate undesirable residues with products. In addition, the extract can suffer oxidative transformations during the solvent's removal step (Díaz-Reinoso et al., 2006).

Based on the optimum treatment parameter values (solvent concentration of $50 \%$, power level of $700 \mathrm{~W}$, and $2.42 \mathrm{~min}$ of extraction time) for maximizing phenolics, the best resulting MAE process was used to compare the total phenolic content. An amount of $2.82 \pm 0.05$ and $2.27 \pm 0.04 \mathrm{mg} \mathrm{GAE} / \mathrm{g}$ DW of phenolics were extracted when UAE (60 $\mathrm{min})$ and maceration $(60 \mathrm{~min})$ extraction techniques were used. MAE, after 2.42 min of extraction, not only reduced the extraction time and the solvent's consumption but also gave a higher yield of phenolics compared to the time consuming UAE and classical-extraction technique which was $4.27 \pm 0.09 \mathrm{mg}$ $\mathrm{GAE} / \mathrm{g}$ DW.

Several scientific investigations report the MAE applicability for obtaining natural antioxidants, without generating undesirable residues (Li et al., 2011; Song et al., 2011; Sutivisedsak et al., 2010). In general, the antioxidant activity of the extracts obtained by MAE is higher than the activity of the extracts obtained by conventional techniques, because the microwave treatment does not cause any deterioration of the antioxidant properties of the extract (Li et al., 2012). MAE process is short, usually from $2 \mathrm{~min}$ to $40 \mathrm{~min}$. This fact makes MAE an attractive technique, only for thermolabile compounds, although long extraction times can result in the degradation and consequent antioxidant capacity loss (Li et al., 2011).

The comparison of the total phenolic contents to those reported in the literature showed that they very similar to some studies and in contrast to others. Indeed, the study of Hamad et al. (2015) performed on the extracts of twelve cultivars of Phoenix dactylifera L. from Saudi Arabia showed that the total phenols content ranged from 10.4 to $22.1 \mathrm{mg}$ GAE $/ 100 \mathrm{~g}$ DW. In addition, a study by Biglari et al. (2008) showed that the total polyphenols content of dates from Iran ranged from 2.89 to $6.64 \mathrm{mg} \mathrm{GAE} / 100 \mathrm{~g}$ DW, with the exception of the Kharak variety, whose total polyphenols content was $141.35 \mathrm{mg}$ GAE/100g DW. The study done by AlFarsi et al. (2007) showed that the total phenols content of the aqueous extracts of three date varieties (Mabseeli, Um-sellah and Shahal) from Omania was between 172 and $246 \mathrm{mg} \mathrm{GAE} / 100 \mathrm{~g}$ DW. Kchaou et al. (2013) tested the extracts of the date varieties of Tunisia, they found that the total phenolic content varied between 240.38 to $505.49 \mathrm{mg} \mathrm{GAE} / 100 \mathrm{~g}$ DW. Taking into account the obtained results, the MAE extract was selected to evaluate the antioxidant activity of dates.

The antioxidant potential of the phenolic extract in terms of the DPPH radical scavenging activity may be due to the existence of hydroxyls in the phenolic extract's molecule, which could be as an electron donator and transfer electron to the DPPH free radical (Krings and Berger, 2001). The percentage of the free radical DPPH inhibition was $58.72 \pm 0.29 \%$. The reducing power of the phenolic extract was $1.88 \pm 0.09 \mathrm{mg}$ AscAE $/ \mathrm{mL}$. The reducing capacity of a compound may serve as an indicator of the potential antioxidant activity for date. Guo et al. (2003) reported that the date has the second highest antioxidant activity among 28 fruits 
commonly consumed in China. On the other hand, it should be recalled that the phenolic profile of dates has revealed that the main phenolic compounds present in dates are cinnamic, ferulic and sinapic acids and their derivatives, as well as flavonoids (Mansouri et al., 2005). According to Cuvelier et al. (1992), caffeic, sinapic and ferulic acids are more active than protocatechic, syringic, vanillic and p-hydroxybenzoic acids.

\section{RP-HPLC-PAD-ESI-MS/MS analysis}

The RP-HPLC-PAD-ESI-MS/MS screening of the dates' extract obtained by microwave-assisted extraction (MAE), was illustrated in the HPLC-UV (254 nm) chromatogram (Figure 2), which exhibited numerous peaks, the peaks being numbered following the elution order (compounds 1-44).

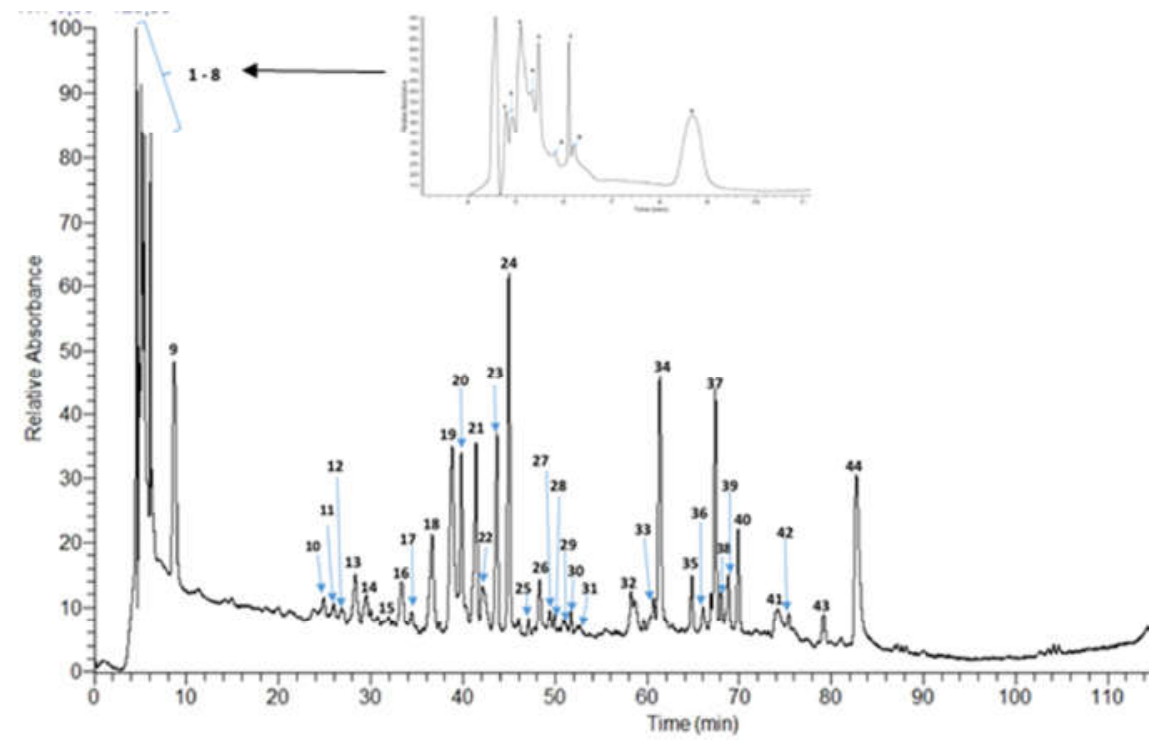

Figure 2. HPLC chromatogram of the date's extract recorded at $254 \mathrm{~nm}$ (inserted figure represents the magnification of the first 11 minutes of HPLC chromatogram).

Tables 4, 5, 6, 7, 8 and 9 show different compounds (sugars, organic acids, nucleosides, carotenoids, proanthocyanidins, lignans, flavonols, flavones, saponin and sterol glucosides) that grouped according to their structural similarity and following their elution order, as well as the Rt, MS data, UV max. and $\mathrm{MS}^{\mathrm{n}}$ fragmentation pattern. In the chromatographic profile, there was a large peak (3) with an UV spectrum corresponding to gluconic acid disaccharide.

\section{Sugars and organic acids}

The first compounds to elute from the C18 column, as it could be predicted, were the sugars and organic acids as they were detected only in the negative ionization mode (Table 4). 
Table 4. RP-HPLC-PAD-ESI-MS/MS analysis of sugars and organic acids.

\begin{tabular}{|c|c|c|c|c|c|c|c|}
\hline $\begin{array}{l}\text { Peak } \\
\text { No }\end{array}$ & $\begin{array}{l}\text { RT } \\
(\mathbf{m i n})\end{array}$ & $\begin{array}{l}\boldsymbol{\Lambda} \\
\text { Max } \\
(\mathbf{n m})\end{array}$ & $\begin{array}{l}{[\mathbf{M}-} \\
\mathbf{H}]^{-}\end{array}$ & $\begin{array}{l}\text { Fragments } \\
{[\mathrm{M}-\mathrm{H}]^{-}} \\
\text {found }\end{array}$ & {$[\mathbf{M}+\mathbf{H}]^{+}$} & $\begin{array}{l}\text { Fragments } \\
{[\mathrm{M}+\mathrm{H}]^{+}} \\
\text {found }\end{array}$ & $\begin{array}{l}\text { Proposed } \\
\text { structure }\end{array}$ \\
\hline \multicolumn{8}{|c|}{ SUGARS AND ORGANIC ACIDS } \\
\hline 1 & 4.80 & $\begin{array}{l}226, \\
265\end{array}$ & $\begin{array}{l}387 / \\
341\end{array}$ & $\begin{array}{l}341(100) \rightarrow \\
179(<5)\end{array}$ & & & Dihexoside \\
\hline 2 & 4.92 & $\begin{array}{l}226 \\
263\end{array}$ & 537 & $\begin{array}{l}537 \rightarrow 195 \\
(100), \\
177(10)\end{array}$ & 1 & l & $\begin{array}{l}\text { Gluconic acid } \\
\text { disaccharide } \\
\text { adduct }\end{array}$ \\
\hline 3 & 5.11 & $\begin{array}{l}226 \\
264\end{array}$ & 537 & $\begin{array}{l}537 \rightarrow 195 \\
(100), \\
177(10)\end{array}$ & 1 & 1 & $\begin{array}{l}\text { Gluconic acid } \\
\text { disaccharide } \\
\text { adduct }\end{array}$ \\
\hline 4 & 5.30 & $\begin{array}{l}226 \\
264\end{array}$ & 537 & $\begin{array}{l}537 \rightarrow 195 \\
(100), \\
177(10)\end{array}$ & 1 & l & $\begin{array}{l}\text { Gluconic acid } \\
\text { disaccharide } \\
\text { adduct }\end{array}$ \\
\hline 5 & 5.46 & $\begin{array}{l}226 \\
259\end{array}$ & 537 & $\begin{array}{l}537 \rightarrow 195 \\
(100), \\
177(10)\end{array}$ & l & l & $\begin{array}{l}\text { Gluconic acid } \\
\text { disaccharide } \\
\text { adduct }\end{array}$ \\
\hline 6 & 5.76 & $\begin{array}{l}223 \\
262\end{array}$ & 133 & $\begin{array}{l}133 \rightarrow 115 \\
(100), \\
113(10), \\
87(<5), \\
71(<5)\end{array}$ & l & / & Malic acid \\
\hline 7 & 6.10 & $\begin{array}{l}230 \\
259\end{array}$ & 191 & $\begin{array}{l}191 \\
\rightarrow 111(100), \\
173(30)\end{array}$ & / & l & Citric acid \\
\hline 8 & 6.19 & $\begin{array}{l}226 \\
256\end{array}$ & 191 & $\begin{array}{l}191 \\
\rightarrow 111(100), \\
173(30)\end{array}$ & / & / & Citric acid \\
\hline
\end{tabular}

Peak 1 has been identified as a disaccharide with a $\mathrm{m} / \mathrm{z}$ at 341 , which breaks down to the 179 [M-H-162] fragment ions due to the loss of a hexosyl moiety (Sokeng et al., 2019). Peaks 2, 3, 4 and 5, instead all have the $\mathrm{m} / \mathrm{z}$ of 537[M-H-342] whose fragments lose a disaccharide to give $\mathrm{m} / \mathrm{z} 195$ which corresponds to gluconic acid. Peak 6 has been identified as malic acid at a m/z 133, it breaks to its basic fragment at a $\mathrm{m} / \mathrm{z} 115[\mathrm{M}-\mathrm{H}-\mathrm{H} 20]^{-}$due to the loss of a water molecule.

Peaks 7 and 8 have been identified as citric acid at a m/z of 191, whose fragments give different daughter ions at the $\mathrm{m} / \mathrm{z} 111[\mathrm{M}-\mathrm{H}-80]^{-}$and $173\left[\mathrm{M}-\mathrm{H}-\mathrm{H}_{2} \mathrm{O}\right]^{-}$which are characteristic of its fragmentation pattern. The identification of the sugars and the organic acids was confirmed by comparison to the reference standards.

\section{Nucleoside and carotenoids}

Nucleoside and carotenoids were identified only in the positive ionization mode as described in Table 5. 
Table 5. RP-HPLC-PAD-ESI-MS/MS analysis of nucleoside and carotenoids.

\begin{tabular}{|c|c|c|c|c|c|c|c|}
\hline $\begin{array}{l}\text { Peak } \\
\text { No }\end{array}$ & $\begin{array}{l}\text { RT } \\
\text { (min) }\end{array}$ & $\begin{array}{l}\boldsymbol{\Lambda} \\
\text { Max } \\
(\mathbf{n m})\end{array}$ & $\begin{array}{l}{[\mathbf{M}-} \\
\mathbf{H}]^{-}\end{array}$ & $\begin{array}{l}\text { Fragments } \\
{[\mathrm{M}-\mathrm{H}]^{-}} \\
\text {found }\end{array}$ & {$[\mathbf{M}+\mathbf{H}]^{+}$} & $\begin{array}{l}\text { Fragments } \\
{[\mathrm{M}+\mathrm{H}]^{+}} \\
\text {found }\end{array}$ & $\begin{array}{l}\text { Proposed } \\
\text { structure }\end{array}$ \\
\hline \multicolumn{8}{|c|}{ NUCLEOSIDE AND CAROTENOIDS } \\
\hline 9 & 8.71 & $\begin{array}{l}220 \\
297\end{array}$ & / & / & 268 & $\begin{array}{l}268 \rightarrow 136(100) \\
106(<5)\end{array}$ & Adenosine \\
\hline 20 & 35.49 & $\begin{array}{l}229 \\
282 \\
322\end{array}$ & / & / & 541 & $\begin{array}{l}541 \rightarrow 379 \\
(100), 361(40), \\
306(<5)\end{array}$ & $\begin{array}{l}10 \text {-apo- } \beta \text { - } \\
\text { caroten-10-ol } \\
\text { hexoside }\end{array}$ \\
\hline 21 & 36.66 & $\begin{array}{l}202 \\
232 \\
326\end{array}$ & l & l & 571 & $\begin{array}{l}571 \rightarrow 409 \\
(100), 481(30), \\
443(10), 391 \\
(10)\end{array}$ & $\begin{array}{l}\text { Hexoside of } \\
\text { 3-hydroxy- } \alpha \text { - } \\
\text { apo-10- } \\
\text { carotenoic } \\
\text { acid }\end{array}$ \\
\hline 23 & 38.34 & $\begin{array}{l}233 \\
286 \\
326\end{array}$ & l & l & 703 & $\begin{array}{l}703 \rightarrow 541 \\
(100), 523(20), \\
592(10) \\
541 \rightarrow 379 \\
(100), 361(40), \\
331(10), 460 \\
(<5), 436(<5) \\
\end{array}$ & $\begin{array}{l}10 \text {-apo- } \beta \text { - } \\
\text { caroten-10'ol } \\
\text { dihexoside }\end{array}$ \\
\hline 24 & 39.07 & $\begin{array}{l}232 \\
281 \\
324\end{array}$ & / & l & 733 & $\begin{array}{l}733 \rightarrow 571(100) \\
571 \rightarrow 409 \\
(100), 481(30), \\
443(10), \\
391(10)\end{array}$ & $\begin{array}{l}\text { Disaccharide } \\
\text { of 3-hydroxy- } \\
\alpha \text {-apo-10- } \\
\text { carotenoic } \\
\text { acid }\end{array}$ \\
\hline
\end{tabular}

Peak 9 was identified as adenosine only in the positive ionization mode at $\mathrm{m} / \mathrm{z} 268$, this molecular ion breaks down to $\mathrm{m} / \mathrm{z} 136[\mathrm{M}+\mathrm{H}-132]^{+}$due to the loss of a ribose moiety (Liu et al., 2008). Peak 20 at $\mathrm{m} / \mathrm{z}$ was tentatively identified as 10-apo- $\beta$ caroten-10-ol hexoside, having a molecular ion at $\mathrm{m} / \mathrm{z} 541$ which breaks to 10 -apo$\beta$-caroten-10-ol, its principal fragment at $\mathrm{m} / \mathrm{z} 379$ [M-H-162] due to the loss of a hexosyl moiety, 10-apo- $\beta$-caroten-10-ol then fragments at its turn to $\mathrm{m} / \mathrm{z} 361$ $\left[\mathrm{M}+\mathrm{H}-\mathrm{H}_{2} \mathrm{O}\right]^{+}$and $306[\mathrm{M}+2 \mathrm{H}-56]^{+}$which are characteristic of this molecule (De Rosso and Mercadante, 2007). As previously seen, peak 21 at m/z 571 corresponds to 3-hydroxy- $\alpha$-apo-10-carotenoic acid hexoside. Peak 23 instead at $\mathrm{m} / \mathrm{z} 703$ has been tentatively identified as 10 -apo- $\beta$-caroten-10-ol dihexoside, in fact, it suddenly breaks down to 10 -apo- $\beta$-caroten-10-ol hexoside at $\mathrm{m} / \mathrm{z} 541[\mathrm{M}+\mathrm{H}-162]^{+}$ by the loss of a hexosyl moiety, the resulting 10 -apo- $\beta$-caroten- 10 -ol hexoside then breaks down at its turn as previously described above.

Peak 24 at m/z 733 has been identified as a disaccharide of 3-hydroxy- $\alpha$-apo-10carotenoic acid, it fragments losing a hexosyl moiety to give its monosaccharidic form at $\mathrm{m} / \mathrm{z} 571$ which is 3-hydroxy- $\alpha$-apo-10-carotenoic acid hexoside, this later then losses at its turn another hexose moiety giving rise to the aglicone3-hydroxy- 
$\alpha$-apo-10-carotenoic acid at $\mathrm{m} / \mathrm{z} 409$ which then fragments as reported on Table 5 (Floss et al., 2008).

\section{Proanthocyanidins and lignans}

Like carotenoids, in this chemical characterization, proanthocyanidins were identified only in the positive ionization mode (Table 6).

Table 6. RP-HPLC-PAD-ESI-MS/MS analysis of proanthocyanidins and lignans.

\begin{tabular}{|c|c|c|c|c|c|c|c|}
\hline $\begin{array}{l}\text { Peak } \\
\text { No }\end{array}$ & $\begin{array}{l}\text { RT } \\
(\min )\end{array}$ & $\begin{array}{l}\text { i Max } \\
(\mathrm{nm})\end{array}$ & $\begin{array}{l}{[\mathbf{M}-} \\
\mathbf{H}]^{-}\end{array}$ & $\begin{array}{l}\text { Fragments } \\
{[\mathrm{M}-\mathrm{H}]^{-}} \\
\text {found }\end{array}$ & {$[\mathbf{M}+\mathbf{H}]^{+}$} & $\begin{array}{l}\text { Fragments } \\
{[\mathbf{M}+\mathbf{H}]^{+}} \\
\text {found }\end{array}$ & $\begin{array}{l}\text { Proposed } \\
\text { structure }\end{array}$ \\
\hline \multicolumn{8}{|c|}{ PROANTHOCYANIDINS AND LIGNANS } \\
\hline 13 & 26.20 & $\begin{array}{l}228 \\
277\end{array}$ & / & / & 579 & $\begin{array}{l}427(100), \\
409(60), 291 \\
(50), 488 \\
(30)\end{array}$ & $\begin{array}{l}\text { Procyanidin } \\
\text { dimer }\end{array}$ \\
\hline 17 & 34 & $\begin{array}{l}227 \\
278 \\
305\end{array}$ & / & / & 867 & $\begin{array}{l}577(100), \\
409(70), \\
427(60), \\
722(60), \\
715(40), \\
806(30), \\
699(30), \\
741(10), \\
623(<5), \\
553(30), \\
535(30), \\
451(30), \\
323(20)\end{array}$ & $\begin{array}{l}\text { Procyanidin } \\
\text { trimer }\end{array}$ \\
\hline 19 & 26.20 & $\begin{array}{l}228 \\
277\end{array}$ & 523 & $\begin{array}{l}477 \\
(100), \\
361(15)\end{array}$ & & & $\begin{array}{l}\text { Secoisolariciresinol- } \\
\text { O-hexoside }\end{array}$ \\
\hline
\end{tabular}

Peak 13 at m/z 579 has been identified as procyanidin dimer. However, peak 17 at $\mathrm{m} / \mathrm{z} 867$ was tentative identified as procyanidin trimer, it breaks down to its common fragments $577[\mathrm{M}+\mathrm{H}]$ - (Table 6). Peak 19 at $\mathrm{m} / \mathrm{z} 523$ corresponds to secoisolariciresinol- $O$-hexoside. These results are in accordance to the mass spectrum of the reference standard and to the study of Sokeng et al. (2019).

\section{Flavonols and flavones}

Regarding flavonols and flavones, they were identified in the positive as well as in the negative ionization modes (Table 7). Peak 18 at $\mathrm{m} / \mathrm{z} 449$ has been identified as dihydrokaempferol-hexoside in the negative ionization mode. As seen from Table 7 , this molecular ion fragments to its basic fragment ions at m/z 287[M-H-162] 
which is dihydrokaempferol due to the loss of the sugar moiety, 269[M-H-180] due to the loss of the sugar and a water molecule and $431\left[\mathrm{M}-\mathrm{H}-\mathrm{H}_{2} \mathrm{O}\right]^{-}$due to the loss of a water molecule (Mena et al., 2012).

Peak 23 has been identified in the positive ionization mode as 6,8-C-diglucosyl apigenin, it fragmented as reported in Table 7. Peaks 32 and 33 have been identified as kaempferol-3-O-rutinoside with the molecular ion at $\mathrm{m} / \mathrm{z} 595$ in the positive ionization which fragments to ions at $\mathrm{m} / \mathrm{z} 449[\mathrm{M}+\mathrm{H}-146]^{+}$and $287[\mathrm{M}+\mathrm{H}-$ $308]^{+}$due to the loss of rhamnosyl and rutinosyl respectively (Bamawa et al., 2018).

Peak 34 with molecular ions at the m/z 609 and 611, detected in negative and positive ionization modes respectively, was identified as rutin, due to its fragmentation pattern which includes fragment ions typical of quercetin derivatives. Due to the loss of the disaccharide rutinose (fragment ion at $\mathrm{m} / \mathrm{z} 302$ ), it corresponded to [M-H- $\alpha$-L-rhamnopyranosyl- $(1 \rightarrow 6)-\beta-\mathrm{D}$-gluco-pyranose]Peaks 35 and 37 with the respective $\mathrm{m} / \mathrm{z}$ of 607 and 609 in the negative and positive ionization modes, have been identified as chrysoeriol-7-Oneohesperidoside, in both modes, it fragments losing the sugar moiety neohesperidoside (made of rhamnose and glucose) to form the fragment ion chrysoriol at $\mathrm{m} / \mathrm{z} 299$ and 301 in the negative and positive ionization modes respectively. Instead, peak 36 at m/z 463 has been identified only in the positive ionization mode, it has been tentatively identified as chrysoeriol hexoside, it fragments losing the sugar to form the fragment ion chrysoriol at $\mathrm{m} / \mathrm{z} 301[\mathrm{M}+\mathrm{H}-$ $162]^{+}$.

A comparison to the reference standard (rutin) confirmed this result. Peak $39 \mathrm{at} \mathrm{m} / \mathrm{z}$ 447 has been identified only in the negative ionization mode as isorhamnetin-3-Opentoside, it breaks down to its principal fragment at $\mathrm{m} / \mathrm{z} 314[\mathrm{M}-2 \mathrm{H}-132]^{-}$due to the loss of the sugar moiety (Schieber et al., 2002). Peak 40 at $\mathrm{m} / \mathrm{z} 647$ has been identified in the positive ionization mode as isorhamnetin-3-O-rutinoside, it fragments generating the ions at $\mathrm{m} / \mathrm{z} 501[\mathrm{M}+\mathrm{H}+\mathrm{Na}-146]^{+}$and $331[\mathrm{M}+\mathrm{H}+\mathrm{Na}-316]^{+}$ by losing a rhamnosyl unit and isorhamnetinaglicone respectively (De Bertoldi et al., 2012).

Peaks 41 and 42 at m/z 543 have been identified in the negative ionization mode as quercetin-hexosyl-sulphate, this molecular ion breaks to give its principal fragment at $\mathrm{m} / \mathrm{z} 301[\mathrm{M}-\mathrm{H}-242]^{-}$due to the loss of a hexosyl-sulphate moiety. Peak $43 \mathrm{at} \mathrm{m} / \mathrm{z}$ 519 has been identified in the negative ionization mode as isorhamnetin acetylhexoside, it fragments to its basic ions 314[M-2H-204]', 315 [M-H-204] due to the loss of the acetyl-hexoside, it also gives the fragment at $\mathrm{m} / \mathrm{z} 357[\mathrm{M}-\mathrm{H}-162]^{-}$due to the loss of the sugar moiety, others fragments typical of this molecule were reported in Table 7 (Sobeh et al., 2016).

Peak 44 has been identified as chrysoeriolhexosyl sulphate, it has an $\mathrm{m} / \mathrm{z}$ of 541 in the negative ionization mode which fragments tochrysoeriol at $\mathrm{m} / \mathrm{z} 299[\mathrm{M}-\mathrm{H}-$ hexosylsulphate] while in the positive mode it has an $\mathrm{m} / \mathrm{z}$ of 543 which principally fragments tochrysoeriol at $\mathrm{m} / \mathrm{z} 301[\mathrm{M}+\mathrm{H} \text {-hexosyl sulphate }]^{+}$and chrysoeriol hexoside at $\mathrm{m} / \mathrm{z} 463[\mathrm{M}+\mathrm{H}-\mathrm{SO} 4]^{+}$. 
Table 7. RP-HPLC-PAD-ESI-MS/MS analysis of flavonols and flavones.

\begin{tabular}{|c|c|c|c|c|c|c|c|}
\hline $\begin{array}{l}\text { Peak } \\
\text { No }\end{array}$ & $\begin{array}{l}\text { RT } \\
(\min )\end{array}$ & $\begin{array}{l}\mathbf{M} \text { Max } \\
(\mathrm{nm})\end{array}$ & $\begin{array}{l}\text { [M- } \\
\mathbf{H}]^{-}\end{array}$ & $\begin{array}{l}\text { Fragments } \\
{[\mathrm{M}-\mathrm{H}]^{-} \text {found }}\end{array}$ & {$[\mathbf{M}+\mathbf{H}]^{+}$} & $\begin{array}{l}\text { Fragments } \\
{[\mathrm{M}+\mathrm{H}]^{+} \text {found }}\end{array}$ & $\begin{array}{l}\text { Proposed } \\
\text { structure }\end{array}$ \\
\hline \multicolumn{8}{|c|}{ FLAVONOLS AND FLAVONES } \\
\hline 18 & 37.07 & $\begin{array}{l}218, \\
274, \\
305\end{array}$ & 449 & $\begin{array}{l}287(100) \\
269(40), 431(30) \\
243(10)\end{array}$ & / & / & $\begin{array}{l}\text { Dihydrokaempferol } \\
\text { hexoside }\end{array}$ \\
\hline 23 & 38.34 & $\begin{array}{l}233 \\
286, \\
326\end{array}$ & / & / & 595 & $\begin{array}{l}\text { 577(100), } \\
457(50), 475(20), \\
559(40), 528(30)\end{array}$ & $\begin{array}{l}\text { 6,8-C- } \\
\text { diglucosylapigenin }\end{array}$ \\
\hline 32 & 58,2 & $\begin{array}{l}233 \\
268 \\
333\end{array}$ & / & / & 595 & 449(100), 287(30) & $\begin{array}{l}\text { Kaempferol-3-O- } \\
\text { rutinoside }\end{array}$ \\
\hline 33 & 61.00 & $\begin{array}{l}234 \\
268, \\
324\end{array}$ & / & / & 595 & $287(100), 433(30)$ & $\begin{array}{l}\text { Kaempferol- 3-O- } \\
\text { rutinoside }\end{array}$ \\
\hline 34 & 61.31 & $\begin{array}{l}255 \\
352 \\
377\end{array}$ & 609 & $\begin{array}{l}301(100), \\
343(15), 271(15), \\
179(<5)\end{array}$ & 611 & $\begin{array}{l}515(100), 465(60), \\
303(60), 345(50), \\
417(40), 382(30), \\
494(30), 543(30)\end{array}$ & Rutin \\
\hline 35 & 64.20 & $\begin{array}{l}234 \\
268, \\
332\end{array}$ & / & / & 609 & $\begin{array}{l}463(100), \\
301(15)\end{array}$ & $\begin{array}{l}\text { chrysoeriol-7-O- } \\
\text { neohesperid- oside }\end{array}$ \\
\hline 36 & 56.50 & $\begin{array}{l}234 \\
272 \\
319\end{array}$ & / & / & 463 & $301(100)$ & $\begin{array}{l}\text { Chrysoeriol } \\
\text { hexoside }\end{array}$ \\
\hline 37 & 67.45 & $\begin{array}{l}234, \\
268, \\
333\end{array}$ & 653 & $299(100), 284(50)$ & 609 & 301(100), 463(30) & $\begin{array}{l}\text { chrysoeriol-7-O- } \\
\text { neohesperi-doside }\end{array}$ \\
\hline 39 & 68.99 & $\begin{array}{l}253 \\
267 \\
344\end{array}$ & 447 & $\begin{array}{l}314(100), \\
357(20), 285(10), \\
179(<5), 152(<5), \\
399(<5), 329(<5)\end{array}$ & / & / & $\begin{array}{l}\text { Isorhamnetin-3-O- } \\
\text { pentoside }\end{array}$ \\
\hline 40 & 69.94 & $\begin{array}{l}255, \\
268, \\
346, \\
377\end{array}$ & / & / & 647 & $\begin{array}{l}501(90), 331(100), \\
619(10), 489(10), \\
338(10)\end{array}$ & $\begin{array}{l}\text { Isorhamnetin-3-O- } \\
\text { rutinoside }\end{array}$ \\
\hline 41 & 74.19 & $\begin{array}{l}247, \\
268, \\
338, \\
377\end{array}$ & 543 & 301(100), 229(10) & / & / & $\begin{array}{l}\text { Quercetin hexosyl } \\
\text { sulfate }\end{array}$ \\
\hline 42 & 74.46 & $\begin{array}{l}247 \\
268 \\
338 \\
377\end{array}$ & 543 & 301(100), 229(10) & / & / & $\begin{array}{l}\text { Quercetin hexosyl } \\
\text { sulfate }\end{array}$ \\
\hline 43 & 79 & $\begin{array}{l}215 \\
311 \\
376\end{array}$ & 519 & $\begin{array}{l}314(100), \\
315(30), 357(15), \\
257(40), 491(20), \\
459(10), 223(10)\end{array}$ & / & / & $\begin{array}{l}\text { Isorhamnetinac- } \\
\text { etyl hexoside }\end{array}$ \\
\hline 44 & 82.74 & $\begin{array}{l}251 \\
347\end{array}$ & 541 & 299(100), 24(30) & 543 & $\begin{array}{l}301(100), \\
463(30), 504(10)\end{array}$ & $\begin{array}{l}\text { Chrysoeriol } \\
\text { hexosyl sulfate }\end{array}$ \\
\hline
\end{tabular}

Saponin and sterol glucosides

From the HPLC-PDA-ESI-MS/MS analysis, eleuthoroside E formate adduct and disaccharide formate adduct have been identified (Table 8). 
Table 8. RP-HPLC-PAD-ESI-MS/MS analysis of saponin and sterol glucosides.

\begin{tabular}{|c|c|c|c|c|c|c|c|}
\hline $\begin{array}{l}\text { Peak } \\
\text { No }\end{array}$ & $\begin{array}{l}\text { RT } \\
(\mathbf{m i n})\end{array}$ & $\begin{array}{l}\boldsymbol{\Lambda} \\
\text { Max } \\
(\mathbf{n m})\end{array}$ & $\begin{array}{l}{[\mathbf{M}-} \\
\mathbf{H}]^{-}\end{array}$ & $\begin{array}{l}\text { Fragments } \\
{[\mathrm{M}-\mathrm{H}]^{-} \text {found }}\end{array}$ & {$[\mathbf{M}+\mathbf{H}]^{+}$} & $\begin{array}{l}\text { Fragments } \\
{[\mathrm{M}+\mathrm{H}]^{+}} \\
\text {found }\end{array}$ & $\begin{array}{l}\text { Proposed } \\
\text { structure }\end{array}$ \\
\hline \multicolumn{8}{|c|}{ SAPONIN AND STEROL GLUCOSIDES } \\
\hline 25 & 47.02 & $\begin{array}{l}202, \\
238, \\
301, \\
378\end{array}$ & 1111 & $\begin{array}{l}949(100), \\
787(100) \\
741(80), \\
579(100), \\
353(30), \\
625(20) \\
579(100) \rightarrow \\
417(100)\end{array}$ & / & / & $\begin{array}{l}\text { Eleutheroside } \\
\mathrm{E} \\
\text { disacchardide } \\
\text { formate } \\
\text { adduct }\end{array}$ \\
\hline 26 & 48.29 & $\begin{array}{l}202, \\
240, \\
281, \\
318, \\
377\end{array}$ & 787 & $\begin{array}{l}741(100) \rightarrow \\
579(100), \\
353(65), \\
579(100) \rightarrow \\
417(100)\end{array}$ & / & l & $\begin{array}{l}\text { Eleutheroside } \\
\text { E formate } \\
\text { adduct }\end{array}$ \\
\hline
\end{tabular}

Peak 25 at the m/z 1111 has been identified as eleuthoroside $\mathrm{E}$ disaccharide formate adduct, it fragments losing the disaccharide and the formic acid to give the fragment ion eleuthoroside at the $\mathrm{m} / \mathrm{z} 741$ which then fragments as previously described (Xiao et al., 2018). In fact, peak 26 at the $\mathrm{m} / \mathrm{z} 787$ in the negative ionization mode breaks down releasing formic acid to give the fragment ion at the $\mathrm{m} / \mathrm{z} 741$ which corresponds to eleuthoroside E. Eleuthoroside E then breaks in turn to the give the fragment ions 579 and 417 due to the loss of one and two glucose moieties, respectively.

\section{Unknown compounds}

Peaks 10, 11, 12, 14, 15, 16, 20, 22, 27, 28, 29, 30 and 31 were not identified either in the negative or the positive ionization modes (Table 9).

Numerous studies have focused on the identification of phenolic compounds in the dates' extracts by HPLC analysis. Indeed, the study of Saleh et al. (2011) assessed the rutin, caffeic acid and catechin contents of the methanolic extracts of Phoenix dactylifera L. cultivars grown in Saudi Arabia. Boudries et al. (2007) noted that the chromatographic analyses of the Algerian varieties of Phoenix dactylifera L. revealed the dominance of the carotenoid pigments represented by lutein and $\beta$ carotene.

Dhaouadi et al. (2010) quantified the phenolic compounds, gallic acid, vanillic acid, cinnamic acid, 3,4-dicaffeoylquinic acid, 5-O-caffeoylshikimic, caffeoylsinapylquinic acid and caffeic acid, coumaric acid, in the aqueous extract of the Deglet-Nour variety grown in Tunisia. Similarly, the phenolic profile of the hydroacetonic extracts of three Tunisian date cultivars established by Kchaou et al. (2016) where gallic acid, vanillic acid, caffeic acid, syringic acid, coumaric acid, ferulic acid, sinapic acid and rutin have been identified. The analysis of the 
phenolic compounds of four varieties of Omani date by HPLC revealed the presence of gallic acid, coumaric acid, caffeic acid, vanillic acid and syringic acid (Al Harthi et al., 2015). The chromatographic separation of aqueous and ethanolic extracts from Egyptian date cultivars revealed the presence of gallic acid, tannic acid and ferulic acid, respectively. In contrast, the study reported the absence of cinnamic acid (El Sohaimy et al., 2015). The differences between our results and those in the literature can be attributed to the geographical origin of the fruits (Al Harthi et al., 2015), the extraction method. In addition, solvent could be at the origin of the variations in the phenolic compounds of the date extract (Kchaou et al., 2013; Shahdadi et al., 2015; Amiour and Hambaba, 2016; Mrabet et al., 2016).

Table 9. RP-HPLC-PAD-ESI-MS/MS analysis of unknown compounds.

\begin{tabular}{|c|c|c|c|c|c|c|c|}
\hline $\begin{array}{l}\text { Peak } \\
\text { No }\end{array}$ & $\begin{array}{l}\text { RT } \\
(\mathrm{min})\end{array}$ & $\begin{array}{l}\kappa \\
\operatorname{Max} \\
(\mathbf{n m})\end{array}$ & $\begin{array}{l}{[\mathbf{M}-} \\
\mathbf{H}]^{-}\end{array}$ & $\begin{array}{l}\text { Fragments } \\
{[\mathrm{M}-\mathrm{H}]^{-}} \\
\text {found }\end{array}$ & {$[\mathbf{M}+\mathbf{H}]^{+}$} & $\begin{array}{l}\text { Fragments } \\
{[\mathbf{M}+\mathbf{H}]^{+} \text {found }}\end{array}$ & $\begin{array}{l}\text { Proposed } \\
\text { structure }\end{array}$ \\
\hline \multicolumn{8}{|c|}{ UNKNOWN COMPOUNDS } \\
\hline $\begin{array}{l}10,11, \\
12,15, \\
20,22, \\
27,28, \\
29,30, \\
31\end{array}$ & / & / & / & / & / & / & / \\
\hline 14 & 28 & $\begin{array}{l}228 \\
278 \\
309 \\
\end{array}$ & / & / & 449 & $\begin{array}{l}335(100), \\
317(80), 274(30), \\
214(10), 143(<5)\end{array}$ & / \\
\hline 16 & 34 & $\begin{array}{l}224 \\
278\end{array}$ & / & / & / & $\begin{array}{l}317(100), 335(50), \\
336(20), 403(10), \\
463(10), 241(10), \\
189(<59\end{array}$ & / \\
\hline
\end{tabular}

\section{Conclusions}

The use of the common dates with low market value for the extraction of beneficial phytonutrients such as phenolic antioxidants not only provides health benefits but also adds values to the waste. The aim of this work was to characterize the phytochemical composition of the phenolic extract after the optimization of the microwave-assisted extraction using the response surface methodology that was chosen as the best method of extracting the phenolic compounds compared to ultrasound-assisted and conventional extractions, and evaluating the in vitro antioxidant activity of the extract in question. The antioxidant activity of the optimized extract was evaluated and compared using the following methods: the DPPH and the reducing power assays with the characterization of the dates extract metabolic profile by RP-HPLC-PAD-ESI-MS/MS. This study scientifically validated the use of dates in traditional medicine and revealed their interest in the context of exploitation in the field of biotechnology. The future work will focus on the optimization and large scale extraction of the selected phytonutrients from dates and their use as food additives. 


\section{Acknowledgments}

We wish to acknowledge the Ministry of Higher Education and Scientific Research of Algeria and the Department of Drug Sciences, Medicinal Chemistry and Pharmaceutical Technology Section, University of Pavia, Pavia, Italy.

\section{References}

Abbès, F., Kchaou, W., Blecker, C., Ongena, M., Lognay, G., Attia, H., Besbes, S. 2013. Effect of processing conditions on phenolic compounds and antioxidant properties of date syrup. Industrial Crops and Products, 44, 634-642.

Abu-Reidah, I.M., Gil-Izquierdo, Á., Medina, S., Ferreres, F. 2017. Phenolic composition profiling of different edible parts and by-products of date palm (Phoenix dactylifera L.) by using HPLC-DAD-ESI/MSn. Food Research International, 100, 494-500.

Al-Farsi, M., Alasalvar, C., Al-Abid, M., Al-Shoaily, K., Al-Amry, M., Al-Rawahy, F. 2007. Compositional and functional characteristics of dates, syrups, and their byproducts. Food Chemistry, 104(3), 943-947.

Al Harthi, S., Mavazhe, A., Al Mahroqi, H., Khan, S. 2015. Quantification of phenolic compounds, evaluation of physicochemical properties and antioxidant activity of four date (Phoenix dactylifera L.) varieties of Oman. Journal of Taibah University Medical Sciences, 10(3), 346-352.

Al-Turki, S., Shahba, M.A., Stushnoff, C. 2010. Diversity of antioxidant properties and phenolic content of date palm (Phoenix dactylifera L.) fruits as affected by cultivar and location. J. Food Agric. Environ, 8(1), 253-260.

Amiour, S.D., Hambaba, L. 2016. Effect of pH, temperature and some chemicals on polyphenoloxidase and peroxidase activities in harvested Deglet Nour and Ghars dates. Postharvest Biology and Technology, 111, 77-82.

Ballard, T.S., Mallikarjunan, P., Zhou, K., O'Keefe, S. 2010. Microwave-assisted extraction of phenolic antioxidant compounds from peanut skins. Food Chemistry, 120(4), 1185-1192.

Bamawa, C., Ndjele, L., Foma, F. 2016. Characterization of leaf phenolic compounds of Sabicea johnstonii by HPLC-MS ${ }^{\mathrm{n}}$. Journal of Natural Products and Resources, 2(2), 86-89.

Besbes, S., Drira, L., Blecker, C., Deroanne, C., Attia, H. 2009. Adding value to hard date (Phoenix dactylifera L.): compositional, functional and sensory characteristics of date jam. Food Chemistry, 112(2), 406-411.

Biglari, F., AlKarkhi, A.F., Easa, A.M. 2008. Antioxidant activity and phenolic content of various date palm (Phoenix dactylifera) fruits from Iran. Food Chemistry, 107(4), 16361641.

Boudries, H., Kefalas, P., Hornero-Méndez, D. 2007. Carotenoid composition of Algerian date varieties (Phoenix dactylifera) at different edible maturation stages. Food Chemistry, 101(4), 1372-1377.

Camel, V. 2000. Microwave-assisted solvent extraction of environmental samples. TrACTrends in Analytical Chemistry, 19(4), 229-248.

Chan, C.H., Yusoff, R., Ngoh, G.C. 2014. Optimization of microwave-assisted extraction based on absorbed microwave power and energy. Chemical Engineering Science, 111, 41-47.

Chandrasekaran, M., Bahkali, A.H. 2013. Valorization of date palm (Phoenix dactylifera) fruit processing by-products and wastes using bioprocess technology-Review. Saudi Journal of Biological Sciences, 20(2), 105-120. 
Chemat, F., Abert-Vian, M., Fernandez, X. 2012. Microwave-assisted extraction of essential oils and aromas. In Microwave-assisted extraction for bioactive compounds, Springer, Boston, MA., 53-68.

Chibane, H., Benamara, S., Noui, Y., Djouab, A. 2007. Some physicochemical and morphological characterizations of three varieties of Algerian common dates. European Journal of Scientific Research, 18(1), 134-140.

Chu, Y.F., Sun, J., Wu, X., Liu, R.H. 2002. Antioxidant and antiproliferative activities of common vegetables. Journal of Agricultural and Food Chemistry, 50(23), 6910-6916.

Cuvelier, M.E., Richard, H., Berset, C. 1992. Comparison of the antioxidative activity of some acid-phenols: structure-activity relationship. Bioscience, Biotechnology, and Biochemistry, 56(2), 324-325.

Dai, J., Yaylayan, V.A., Raghavan, G.V., Parè, J.R. 1999. Extraction and colorimetric determination of azadirachtin-related limonoids in neem seed kernel. Journal of Agricultural and Food Chemistry, 47(9), 3738-3742.

De Bertoldi, C., De Leo, M., Ercoli, L., Braca, A. 2012. Chemical profile of Festuca arundinacea extract showing allelochemical activity. Chemoecology, 22(1), 13-21.

De Rosso, V.V., Mercadante, A.Z. 2007. Identification and quantification of carotenoids, by HPLC-PDA-MS/MS, from Amazonian fruits. Journal of Agricultural and Food Chemistry, 55(13), 5062-5072.

Dhaouadi, K., Raboudi, F., Estevan, C., Barrajón, E., Vilanova, E., Hamdaoui, M., Fattouch, S. 2010. Cell viability effects and antioxidant and antimicrobial activities of Tunisian date syrup (Rub El Tamer) polyphenolic extracts. Journal of Agricultural and Food Chemistry, 59(1), 402-406.

Díaz-Reinoso, B., Moure, A., Domínguez, H., Parajó, J.C. 2006. Supercritical $\mathrm{CO}_{2}$ extraction and purification of compounds with antioxidant activity. Journal of Agricultural and Food Chemistry, 54(7), 2441-2469.

Djaoud, K., Arkoub-Djermoune, L., Remini, H., Sait, S., Tazarourte, M., Hadjal, S., Romero, A., Madani, K., Boulekbache-Makhlouf, L. 2019. Syrup from common date variety (Phoenix dactylifera L.): Optimization of sugars extraction and their quantification by High Performance Liquid Chromatography. Current Nutrition \& Food Science, 15, 1-13.

Djaoud K., Boulekbache-Makhlouf L., Yahia M., Mansouri H., Mansouri N., Madani K., Romero A. 2020. Dairy dessert processing: Effect of sugar substitution by date syrup and powder on its quality characteristics. Journal of Food Processing and Preservation. e14414.

El Sohaimy, S., Abdelwahab, A., Brennan, C.S., Aboul-Enein, A. 2015. Phenolic content, antioxidant and antimicrobial activities of Egyptian date palm (Phoenix dactylifera L.) fruits. Australian Journal of Basic and Applied Sciences, 9(1), 141-147.

Esclapez, M., García-Pérez, J.V., Mulet, A., Cárcel, J. 2011. Ultrasound-assisted extraction of natural products. Food Engineering Reviews, 3(2), 108.

Floss, D.S., Schliemann, W., Schmidt, J., Strack, D., Walter, M.H. 2008. RNA interferencemediated repression of MtCCD1 in mycorrhizal roots of Medicago truncatula causes accumulation of $\mathrm{C} 27$ apocarotenoids, shedding light on the functional role of CCD1. Plant Physiology, 148(3), 1267-1282. 
Georgé, S., Brat, P., Alter, P., Amiot, M.J. 2005. Rapid determination of polyphenols and vitamin C in plant-derived products. Journal of Agricultural and Food Chemistry, 53(5), 1370-1373.

Guo, C., Yang, J., Wei, J., Li, Y., Xu, J., Jiang, Y. 2003. Antioxidant activities of peel, pulp and seed fractions of common fruits as determined by FRAP assay. Nutrition Research, 23(12), 1719-1726.

Hamad, I., Abd Elgawad, H., Al Jaouni, S., Zinta, G., Asard, H., Hassan, S., Hegab, M., Hagagy, N., Selim, S. 2015. Metabolic analysis of various date palm fruit (Phoenix dactylifera L.) cultivars from Saudi Arabia to assess their nutritional quality. Molecules, 20(8), 13620-13641.

Kchaou, W., Abbès, F., Blecker, C., Attia, H., Besbes, S. 2013. Effects of extraction solvents on phenolic contents and antioxidant activities of Tunisian date varieties (Phoenix dactylifera L.). Industrial Crops and Products, 45, 262-269.

Kchaou, W., Abbès, F., Mansour, R.B., Blecker, C., Attia, H., Besbes, S. 2016. Phenolic profile, antibacterial and cytotoxic properties of second grade date extract from Tunisian cultivars (Phoenix dactylifera L.). Food Chemistry, 194, 1048-1055.

Krings, U., Berger, R. 2001. Antioxidant activity of some roasted foods. Food Chemistry, 72(2), 223-229.

Li, H., Deng, Z., Wu, T., Liu, R., Loewen, S., Tsao, R. 2012. Microwave-assisted extraction of phenolics with maximal antioxidant activities in tomatoes. Food Chemistry, 130(4), 928-936.

Li, Y., Skouroumounis, G.K., Elsey, G.M., Taylor, D.K. 2011. Microwave-assistance provides very rapid and efficient extraction of grape seed polyphenols. Food Chemistry, 129(2), 570-576.

Liu, R., Ye, Y., Qiang, L., Liao, X., Zhao, Y. 2008. The fragmentation pathway of the nucleosides under the electrospray ionization multi-stage mass spectrometry. Life Science Journal, 5, 37-40.

Mansouri, A., Embarek, G., Kokkalou, E., Kefalas, P. 2005. Phenolic profile and antioxidant activity of the Algerian ripe date palm fruit (Phoenix dactylifera). Food Chemistry, 89(3), 411420.

Mena, P., Calani, L., Dall'Asta, C., Galaverna, G., García-Viguera, C., Bruni, R., Crozier, A., Del Rio, D. 2012. Rapid and comprehensive evaluation of (poly) phenolic compounds in pomegranate (Punica granatum L.) juice by UHPLC-MSn. Molecules, 17(12), 14821-14840.

Milardović, S., Iveković, D., Grabarić, B.S. 2006. A novel amperometric method for antioxidant activity determination using DPPH free radical. Bioelectrochemistry, 68(2), 175-180.

Moraes, M.N., Zabot, G.L., Prado, J.M., Meireles, M.A.A. 2013. Obtaining antioxidants from botanic matrices applying novel extraction techniques. Food and Public Health, 3(4), 195-214.

Mrabet, A., Jiménez-Araujo, A., Fernández-Bolaños, J., Rubio-Senent, F., Lama-Muñoz, A., Sindic, M., Rodríguez-Gutiérrez, G. 2016. Antioxidant phenolic extracts obtained from secondary Tunisian date varieties (Phoenix dactylifera L.) by hydrothermal treatments. Food chemistry, 196, 917-924.

Oyaizu, M. 1986. Studies on products of browning reaction. The Japanese Journal of Nutrition and Dietetics, 44(6), 307-315. 
Saleh, E.A., Tawfik, M.S., Abu-Tarboush, H.M. 2011. Phenolic contents and antioxidant activity of various date palm (Phoenix dactylifera L.) fruits from Saudi Arabia. Food and Nutrition Sciences, 2(10), 1134.

Sangamithra, A., Sivakumar, V., Kannan, K., John, S.G. 2015. Foam-mat drying of muskmelon. International Journal of Food Engineering, 11(1), 127-137.

Schieber, A., Keller, P., Streker, P., Klaiber, I., Carle, R. 2002. Detection of isorhamnetin glycosides in extracts of apples (Malus domestica cv."Brettacher") by HPLC-PDA and HPLC-APCI-MS/MS. Phytochemical Analysis: An International Journal of Plant Chemical and Biochemical Techniques, 13(2), 87-94.

Setyaningsih, W., Saputro, I., Palma, M., Barroso, C. 2015. Optimisation and validation of the microwave-assisted extraction of phenolic compounds from rice grains. Food Chemistry, 169, 141-149.

Shahdadi, F., Mirzaei, H., Garmakhany, A.D. 2015. Study of phenolic compound and antioxidant activity of date fruit as a function of ripening stages and drying process. Journal of Food Science and Technology, 52(3), 1814-1819.

Sobeh, M., ElHawary, E., Peixoto, H., Labib, R.M., Handoussa, H., Swilam, N., El-Khatib, A.H., Sharapov, F., Mohamed, T., Krstin, S. 2016. Identification of phenolic secondary metabolites from Schotia brachypetala Sond. (Fabaceae) and demonstration of their antioxidant activities in Caenorhabditis elegans. Peer J, 4, e2404.

Sokeng, A.J.T., Sobolev, A.P., Di Lorenzo, A., Xiao, J., Mannina, L., Capitani, D., Daglia, M. 2019. Metabolite characterization of powdered fruits and leaves from Adansonia digitata L.(Baobab): A multi-methodological approach. Food Chemistry, 272, 93-108.

Song, J., Li, D., Liu, C., Zhang, Y. 2011. Optimized microwave-assisted extraction of total phenolics (TP) from Ipomoea batatas leaves and its antioxidant activity. Innovative Food Science \& Emerging Technologies, 12(3), 282-287.

Sutivisedsak, N., Cheng, H., Willett, J., Lesch, W., Tangsrud, R., Biswas, A. 2010. Microwave-assisted extraction of phenolics from bean (Phaseolus vulgaris L.). Food research international, 43(2), 516-519.

Swamy, G.J., Sangamithra, A., Chandrasekar, V. 2014. Response surface modeling and process optimization of aqueous extraction of natural pigments from Beta vulgaris using Box-Behnken design of experiments. Dyes and Pigments, 111, 64-74.

Takeuchi, T.M., Pereira, C.G., Braga, M.E., Maróstica Jr, M.R., Leal, P.F., Meireles, M.A.A. 2008. Low-pressure solvent extraction (solid-liquid extraction, microwave assisted, and ultrasound assisted) from condimentary plants. In Extracting Bioactive Compounds for Food Products. CRC Press, 150-231.

Venkatesh, M., Raghavan, G. 2004. An overview of microwave processing and dielectric properties of agri-food materials. Biosystems Engineering, 88(1), 1-18.

Xiao, Y., Liu, L., Bian, J., Yan, C., Ye, L., Zhao, M., Huang, Q., Wang, W., Liang, K., Shi, Z. 2018. Identification of multiple constituents in shuganjieyu capsule and rat plasma after oral administration by ultra-performance liquid chromatography coupled with electrospray ionization and ion trap mass spectrometry. Acta Chromatographica, 30(2), 95-102. 